\title{
K to 12 Assessment: The Periodic Way
}

\author{
Lynn M. Besa \\ Rizal Technological University, \\ Mandaluyong, Philippines
}

Jazel C. Erquiza

Eulogio Rodriguez Integrated School-DepEd Mandaluyong, Philippines

\section{Richard E. Parcon}

Tañong High School, DepEd Marikina, Philippines

\begin{abstract}
Testing shows a versatility feature of social life (McNamara, 2010: p. 25) yet the traditional way of assessing learner's progress have sustained in most language classrooms which brought a gap between the intended outcome and the way it is achieved. Therefore, what should be assessed and how learning should be assessed in order to assure that the students have acquired the expected competencies? K-12 program clear out that classroom assessment should be based on the curriculum framework and curriculum of guide of every discipline. Assessment should assess the content standard, performance standard, learning competencies and concept development. The researchers prompted to associate the periodical tests provided to the learners and the overall aims of the program and explore the areas of the tests to evaluate its alignment to of learning, as learning and of learning. The researchers made use of quantitative - qualitative approach to evaluate the Grade VII periodical tests used from S.Y. 2014-2018 from the Divisions of Marikina, Pasig, and Mandaluyong Cities. Table of Specifications were utilized as a basis in constructing the test items, which were devised by the researchers in order to have uniformity of the table pattern.
\end{abstract}

Keywords: assessment, competencies, performance, periodical tests, Table of specifications.

\section{Introduction}

Over the years, the inability of the students to meet the standards set certain grade level has always been an issue. Students are noticed to be deficient in their class performance in which tests are in most cases the gauge to assess their achievements. Assessment shows a versatility feature of social life (McNamara, 2000). However, how sure are the test makers that the test items really measure what they aim to measure?

For the past 20 years, extraordinary changes in languages testing had been made (Combee, Purmensky, and Davidson, 2012; Shehadah, 2012; Eslami, Z and Mirzaei, 2012). In the execution of the Enhanced Basis Education of Act 2013 (Republic Act No. 10533), the Department of Education (DepEd) order No. 8 series of 2015 set a Policy on Guidelines on Classroom Assessment for the K to 12 Basic Education Program. It is very clear that classroom assessment should be based on the curriculum framework and curriculum of guide of every discipline. Assessment should assess the content standard, performance standard, learning competencies and concept development as reflected in the K-12 English Curriculum guide from grades 1 to 10. As such, eight (8) domains of language; reading comprehension, listening comprehension, viewing comprehension, vocabulary development, literature, writing composition, oral language and fluency, and grammar awareness 
should be reflected in both teaching and assessment. In terms of concept development, the curriculum reflects progressions of concept and development using Anderson and Krathwohl (2001) cognitive process dimensions (Coggins and Colburn, 2018).

At the end of the every grading period, a summative or quarterly assessment is given. The goal of summative quarterly assessment is to determine the learner's progress at the end of every unit by comparing it to a specific standard. Quarterly summative tests are often high stakes, that contains a high point value. The researcher in this study tried to find out if the test given among the test takers assessed the competencies specified in the $\mathrm{K}$ to 12 curriculum guide. Hence, it tried to seek a response to the following sub-problems:

1. What are the contents of the tests?

2. What are the general features of the test?

3. Are the tests compliant to the $\mathrm{K}$ to 12 curriculum guide?

The result of this research is intended to compare the test given to the learners and the intended outcome of the program. Thus, this study intended to explore the areas the tests assessed. Moreover, the result of this research will serve as an eye opener to the test constructor in order to account various factors in test construction other than to assess the level of students' knowledge acquisition which hoped to eventually lead to the improvement of the assessment given to students who are expected to become fluent and proficient communicators. In addition, the analysis of the sample tests aimed to evaluate periodic testing as a form of evaluation in the $\mathrm{K}$ to 12 assessment area as to its alignment to of learning, as learning and of learning.

\section{Method}

\section{Design}

The research is both quantitative and qualitative in nature. The researchers made use of mix method design since items in the periodic test were analyzed, categorized, and itemized (based on the topics, competencies, and level of comprehension anchored with the revised Bloom's Taxonomy by Lorin Anderson and David Krathwohl). As the researchers collected, analyzed, explored, and deduced data from the given Grade 7 periodic tests, hence, content analysis was used in order to determine the appositeness of the periodic test assessment to the K-12 Curriculum.

\section{Materials}

The Grade VII periodical tests used in the research were taken from S.Y. 2014-2018 from the Divisions of Marikina, Pasig, and Mandaluyong. Table of Specifications were also utilized as the basis in doing the test items, which were devised by the researchers in order to have uniformity of the specification pattern.

\section{Procedure}

In the acquisition of Grade VII test paper, some English VII teachers were request test paper copies while the other copies were provided by colleagues in the field. After the sample of the Grade VII periodic tests were collected, the researchers devised table of specification for each of the available Grade VII periodic test. Then, the data were analyzed, interpreted and presented. 


\section{Results and Discussion}

\section{Contents of the Tests based on the Table of Specification}

Table 1: Sample Table of Specification [of $1^{\text {st }}$ Quarter Examination in the Division of Mandaluyong during the School Year 2017-2018]

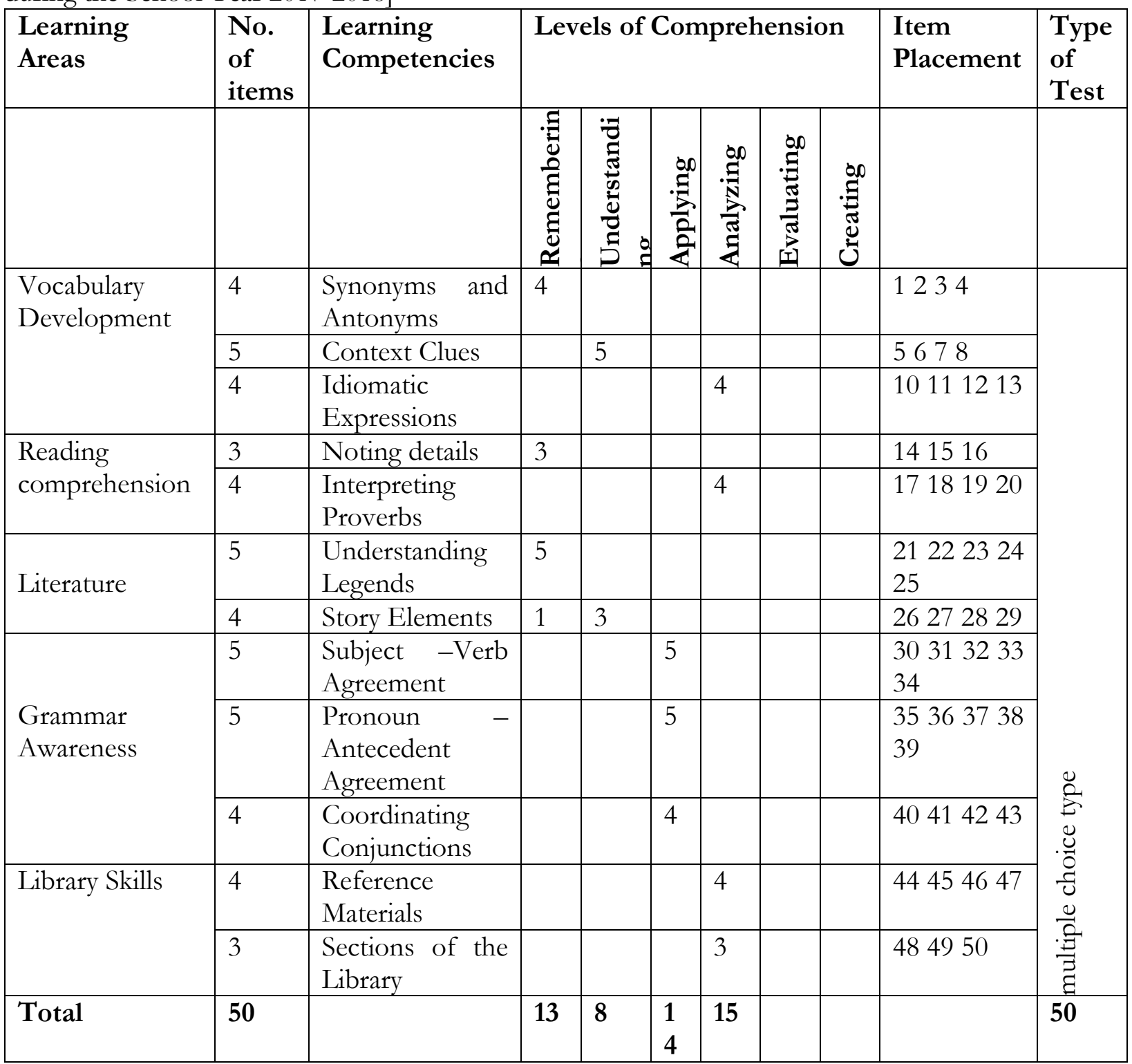

\begin{tabular}{|l|l|l|l|}
\hline Test Parts & Learning Areas & No. of items & Percentage \\
\hline Part I & Vocabulary Development & 13 & 26 \\
\hline Part II & Reading Comprehension & 7 & 14 \\
\hline Part III & Literature & 9 & 18 \\
\hline Part IV & Grammar Awareness & 14 & 28 \\
\hline Part V & Library Skills & 7 & 14 \\
\hline Total & & $\mathbf{5 0}$ & $\mathbf{1 0 0}$ \\
\hline
\end{tabular}

Based on this table of specification, the test dominantly measured the "analyzing" level of comprehension with 15 items, followed by "applying" with 14 items, the "remembering" level of comprehension contains 13 items and the "understanding" level of comprehension contains 8 items. In terms of the skills being tested, only 4 skills were given emphasis in the test, namely reading comprehension, vocabulary development, literature, and grammar awareness. In grammar awareness, there are 3 competencies being tested, first is the observe correct subject-verb agreement which contains 5 item questions in the test, second is the usage of pronoun-antecedent agreement which contains 5 item questions in the test and lastly, observing the coordinating conjunctions in the sentence which contains 4 item question in the test. The next skill being tested is the vocabulary development wherein 2 competencies were measured. First competency under vocabulary development is using the context clues to define a word which contains 5 item questions in the test. 
The second competency is the use of idiomatic expressions in a variety of basic interpersonal communicative situations which contains 4 item questions in the test item. In terms of the literature, there were 3 competencies measured in the test. First, "identify the distinguishing features of proverbs which contain 4 item questions in the test. Second, distinguishing features of legends which contain 5 item questions in the test. Lastly, identify the elements of short story which contains 4 item questions in the test. The last skill being tested as reflected in the table was the reading comprehension wherein 3 competencies measured. First, noting details wherein 3 item questions were placed in the test. Second, determine the reference materials available in the library wherein the 3 item questions allotted in the test. Third, identify the sections of the library, wherein 3 item questions allotted in the test.

Comparing the Table of specification with the competencies reflected in the curriculum guide, there were competencies present in the table of specification which were not covered in the curriculum guide of English 7 for the first quarter. Namely, noting details, story elements, reference materials, sections of the library, and pronoun-antecedent agreement. These competencies were present in other quarter of the curriculum guide. In addition, other skills like writing and composition, and listening comprehension were not included in the skills being measured in the periodical test.

\section{General Features of the Periodical Tests \\ Reading Comprehension dominated tests}

The table shows the summary of learning areas and the percentage of distribution in the tests.

Table 2: Summary of Learning Areas and Percentage of Distribution

\begin{tabular}{|l|l|}
\hline Learning Areas & Percentage of Distribution \\
\hline Listening Comprehension & between $8-24 \%$ \\
\hline Vocabulary Development & between $10-36 \%$ \\
\hline Reading Comprehension & between $14-100 \%$ \\
\hline Literature & between $8-30 \%$ \\
\hline Grammar Awareness & between $8-70 \%$ \\
\hline Writing Composition & between $6-16 \%$ \\
\hline Study Skills & between $8-14 \%$ \\
\hline
\end{tabular}

It could be seen that the highest percentage of distribution is allotted to reading comprehension which is between $14-100 \%$. It was followed by grammar awareness which is between $8-70 \%$ of the total test items. Thus, it could be gleaned from the sample test that most of the items fall under the noting details which answer the W's questions.

\section{Multiple Choice type of test oriented}

The quarterly tests revealed there is a detachment way in testing which is meant to benchmark one content point. The test presented that there is only one possible response for each test item, each test item samples showed a particular element by utilizing one skill (recall), items are not reliant with one another, alteration of one item does not change the learner's performance on the other test items of the test. Hence, it only shows that the learners assimilate the correct response. In addition, the test item can be described as 'closed type' where the learners had to select between a limited number of choices which ensure an 'objective' scoring since whoever marked the test, the scoret would be the same, making it a psychometric.

\section{Lower order type of questions approach}

Table 3: Total Allocation of the Levels of Comprehension

\begin{tabular}{|l|l|}
\hline Levels of Comprehension & No. of Items (from 15 test samples) \\
\hline Remembering & 221 \\
\hline Understanding & 160 \\
\hline Applying & 195 \\
\hline Analyzing & 105 \\
\hline Evaluating & 48 \\
\hline Creating & 17 \\
\hline Total & 750 (for 50 item test) \\
\hline
\end{tabular}


Table 3 shows that among the levels of comprehensions, remembering has the most number of items with 221 counts. Applying has 195 counts and understanding has 160 counts. The distribution of the level of competencies shows that most of the items fall under the lower order thinking skills.

In order to measure level of comprehension in the periodical test, cognitive process dimensions was present which includes the lower order thinking skills and high order thinking skills. However, as reflected in the sample table of specification and test item, most of the tests item constructed were under lower order thinking skills.Few items were constructed under high order thinking skills. According to North (2014), the language levels and level of comprehension, a test constructed in language domains should develop the higher order thinking skills of the test takers. Moreover, Sullivan, (2011) mentioned that, in order to avoid mentioning the item test that measures the various level of comprehension as a receptive type of test, teacher should construct an item under higher order thinking skills. In addition, Green (2012) stated that it should be clear that teacher should determine first the scope of the test in terms of all the cognitive process dimensions and try to counterpart the aim with the test questions that most clearly similar to it.

\section{Proficiency-based test}

It could be gleaned that in the grammar part of the tests, all items are proficiency-based. A proficiency-based test assesses a learner's level of language. However, this kind of tests often have a substantial backwash effect among the test takers as they focus on preparing for the test item (Combee, Troudi, Al-Hamly, 2012)WhileOtaka (2011) pointed out thatproficiency-based tests encouraged students to acquire only the basic reading skills and sufficient grammatical knowledge instead of listening and speaking skills which are essential in speaking and understanding English.

\section{Compliance of the Tests to the $\mathrm{K}$ to 12 Curriculum Guide}

With the purpose of producing graduates who can apply the language protocols, principles, strategies and skills in (1) interrelating with others, (2) understanding and learning other content areas, and (3) fitting themselves in different field of endeavour they may engage in, the K-12 Language Arts and Multi-literacies Curriculum is grounded on language acquisition, learning, teaching and assessing principles

In the article of Farhady (2012) entitled Principles of Language Assessment, assessment should aid the learners in critical thinking and in developing literacy skills that enable them to realize that English language is a dynamic social process, composed with values, beliefs and ways of thinking and mirrors changing social conditions. As such, it is expected that assessment in the $\mathrm{K}$ to 12 program should be aligned with the following characteristics: (1). Closeness to real language use and performance, (2) A general outlook of language, (3). An integrative view of learning and (4) Evolving appropriateness. Table 4 shows the $\mathrm{K}$ to 12 assessment characteristics and the features of the tests.

Table 4: Test Features versus $\mathrm{K}$ to 12 mandates

\begin{tabular}{|l|l|l|}
\hline K to 12 mandates & Tests Features & Remarks \\
\hline $\begin{array}{l}\text { Proximity to actual language } \\
\text { use }\end{array}$ & $\begin{array}{l}\text { Dominantly grammar and } \\
\text { content-based approach test }\end{array}$ & Not aligned \\
\hline $\begin{array}{l}\text { Integrative and holistic view of } \\
\text { language learning }\end{array}$ & Proficiency-based test & Not aligned \\
\hline $\begin{array}{l}\text { Competencies allotment in the } \\
\text { quarter }\end{array}$ & $\begin{array}{l}\text { Some competencies could be } \\
\text { found in the other quarters }\end{array}$ & Not aligned \\
\hline
\end{tabular}

It could be gleaned in the table that test items in grade 7 periodical tests were not aligned with the specifications in the English 7 Curriculum guide. The features revealed that the tests were dominantly grammar and proficiency -based.

Communicative tests aim to measure how the test takers are able to apply language in actual life situations. Morrow (2012). Communicative language tests intend to offer the teacher with inputs about the learners' capability to execute language in specific context-specific tasks. Thus, the fundamental principle of communicative language testing is that the tasks are designed to represent 
realistic activities in the real world. According to Brown (2012) there are five requirements that make up communicative tests. They should be 1) meaningful communication, 2) in an authentic situation, 3) with random language input, 4) resourceful language output, and 5)integrative language skills

Only 6 out of 8 domains were measured and tested. Since the type of test used in the periodical test was multiple choice type of test, oral language and fluency and viewing comprehension were not included in the test. According to the English language and arts Curriculum guide Assessment tries to capture the learner's competencies. It gauges language proficiency and performance in the context.

The data reveals that oral language and fluency and viewing comprehension were not included in the tests which are the major instruments in testing the communicative competence of the test takers. While the biggest percentage in the breakdown of items is allotted to Knowledge or recall-based tests which is categorized as the lowest level of learning. More so, because the periodical tests were paper-based tests, communicative performance in the actual language use was overlooked.

It could also be observed that the periodical tests failed to conform on the authentic, creative and integrative language sample items which should trigger the critical thinking skills and enhance the communicative skills of the learners. Thus, it was observed that the tests samples weren't able to move from the content-based sample items which are discouraged since English subject is literature-based.

The content of the tests including the scope of learning competencies allotted for Grade 7 were not compliant to the DepEd K to 12 curricular program. Learning competencies allotted for a specific quarter is not paralleled as reflected in the sample table of specification. As per advised by the DepEd order no 8 series 2015 target competencies for each quarter should match the test item given in every quarter. In general, the periodical tests samples did not match the specifications in English 7 curriculum guide set by the DepEd.

\section{Conclusion}

Language tests acts a significant role in the lives of many, It serves as gateways in improving educational system. Since language tests plays pivotal role in the learners lives, understanding and careful scrutiny should be given much importance in it (McNamara, 2010). Through tests, teachers discover whether objectives are being achieved. Tests aid the teacher in evaluating the effectiveness of the teaching in general. Language testing is a complex activity. It could be instructive therefore to look at other kinds of tests which do not share these particular difficulties.

According to Tschirner(2018), life is full of tests of varying degrees of formality and important principles can often be seen operating more clearly in non-linguistic tests, where issues are simpler. Extending these principles to language testing can help to think clearly about what tests do and what they are for. The sample tests given to Grade 7 test takers disclosed that not all skills prescribed by DepEd were tested, that the test items were dominantly knowledge and contentbased which measured dominantly the lower level thinking skills, and that the overall coverage of the tests are somewhat divergent from those specified under a certain grade level.

Therefore, objectives of the tests should be clearly envision before designing a test for a specific course. In doing so, the tests could surely indicate the closeness of each student in attaining the objectives while teaching will be rationally oriented (Fulcher and Davidson, 2012).

This study recommends that the teachers ponder primarily the curriculum guide which sets the objectives and competencies to be enhanced. Although the teachers are not barred from constructing knowledge-based tests, task-based tests which enhances communication are highly recommended. As such, performance- based test should be authentic in nature so that students get to perform hands-on tasks (Hilliard, 2015). Also, teacher training in tests construction is highly recommended to reorient and update the test makers on the principles in test making so that they could respond to the emerging issues of testing and evaluation. 


\section{References}

Brown, J. D. (2012). Choosing the Right Type of Assessment. In C. Coombe et al. (Eds.), The Cambrdige Guide to Second Language Assessment. Cambridge University Press.

Coggins, P and Colburn, L. (2018). Guiding Preservice Teachers to Making a Shift in Thinking: Developing Skill and Confidence in Assessment through Thematic Integrated Units. In Anderson, L W and Krathwol David R., A Taxonomy of Learning, Teaching, and Assessing: A Revision of Bloom's Taxonomy of Educational Objectives. $\quad$ Retrieved on November 2018 from https://www.scirp.org/journal/PaperInformation.aspx?PaperID=86500.

Combee, C., Purmensky, K., and Davidson, P. (2012). Alternative Assessment in Language Education. In C. Coombe et al. (Eds.), The Cambrdige Guide to Second Language Assessment. Cambridge University Press.

Combee, C., Troudi, S., and Al-Hamly, M. (2012). Foreign and Second Language Teacher Assessment Literacy: Issues, Challenges, and Recommendations. In C. Coombe et al. (Eds.), The Cambrdige Guide to Second Language Assessment. Cambridge University Press.

DepEd K to 12 Curriculum Guide. (2016). DepEd. Retrieved on September 2018 from www.deped.gov.ph.

Eslami, Z and Mirzaei, A. (2012). Assessment of Second Language Pragmatics. In C. Coombe et al. (Eds.), The Cambrdige Guide to Second Language Assessment. Cambridge University Press.

Fulcher, G and Davidson, F. (2012).The Routledge Handbook of Language Testing. A Handbook. USA: Harcourt, Brace \& World, Inc.

Green, A. (2012). Placement Testing. In C. Coombe et al. (Eds.), The Cambrdige Guide to Second Language Assessment. Cambridge University Press.

Hilliard, P. (2015). Performance-Based Assessment:Reviewing the Basics. Retrieved on September 2018 from https:// www.edutopia.org/blog/performance-based-assessment-reviewing-basics-patricia-hilliard.

Lani, J. (2018). Dissertation and Research Consulting For Statistical Analysis. Retrieved on November 2018 from from. https://www.statisticssolutions.com.

McNamara, T. (2010). Language Testing. HongKong: Oxford University Press.

Morrow, K. (2012). Communicative Language Testing. In C. Coombe et al. (Eds.), The Cambrdige Guide to Second Language Assessment. Cambridge University Press.

Otaka, H. (2011). The Backwash Effect of The Entrance Exam on English Language Education in Japan. Retrieved on November 2018 from http:/ / kwansai.repo.nii.ac.jp.

Policy Guidelines on Classroom Assessment for the K-12 Basic Education Program. (2016). DepEd Order no. 8 Series of 2015. Retrieved on October 2018 from www.DepEd.gov.ph

Shehadeh, A. (2012). Task-Based Language Assessment: Components, Development, and Implementation. In C. Coombe et al. (Eds.), The Cambrdige Guide to Second Language Assessment. Cambridge University Press.

Sullivan, L. (2011). Describing the Language Level. Language Testing. US: Palgrave Macmillan.

Tschirner, E. (2018). Language Testing: Current Practices and Future Developments. Die Unterrichtspraxis/Teaching German, 51(2), 132-143.

\section{About the Authors}

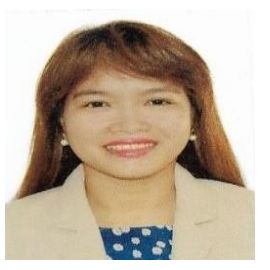

Lynn M. Besa is a full time English faculty of the College of Education in Rizal Technological University. She is a candidate for Ph.D in Applied Linguistics at Philippine Normal University. Ms. Besa is actively engaged in research, education and language studies

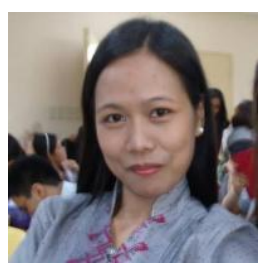

Jazel C. Erquiza is a full time Junior High School English Teacher at Eulogio Rodriguez Integrated School-DepEd Mandaluyong and currently taking her Master of Arts in Literature and Language Instruction at Rizal Technological University. She participated in various conferences and seminar about language teaching.

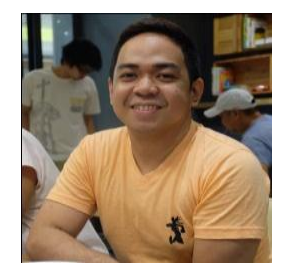

Richard E. Parcon is a full time Senior high school teacher at Tañong High School, DepEd Marikina and a part time English faculty in Rizal Technological University. He handles practical research, education, literature, and Englishsubjects. Mr. Parcon is taking his Doctor of Philosophy in English Language Education at Philippine Normal University The National Center for Teacher Education 